\title{
Erratum to: Selective Hydrolysis of Arabinogalactan into Arabinose and Galactose Over Heterogeneous Catalysts
}

\author{
Bright T. Kusema • Gerd Hilpmann • \\ Päivi Mäki-Arvela $\cdot$ Stefan Willför · \\ Bjarne Holmbom • Tapio Salmi · Dmitry Yu. Murzin
}

Published online: 5 March 2014

(c) Springer Science+Business Media New York 2014

Erratum to: Catal Lett (2011) 141:408-412

DOI 10.1007/s10562-010-0530-x

The original publication contained a typographical error in the surname of one of the authors. The author's name is Gerd Hilpmann, not Gerd Hilmann.

The online version of the original article can be found under doi:10. 1007/s10562-010-0530-x.

B. T. Kusema · G. Hilpmann · P. Mäki-Arvela · S. Willför ·

B. Holmbom · T. Salmi · D. Yu. Murzin ( $₫)$

Laboratory of Industrial Chemistry and Reaction Engineering,

Laboratory of Wood and Paper Chemistry, Department of

Chemical Engineering, Process Chemistry Center, Åbo Akademi

University, 20500 Åbo/Turku, Finland

e-mail:dmurzin@abo.fi 